\title{
Uji Ketahanan Beberapa Galur Padi Smart Hasil Mutasi Radiasi Padi Lokal Aceh Dengan Teknologi Sinar Gamma Terhadap Penyakit Hawar Daun Bakteri (Xanthomonas oryzae pv. oryzae)
}

\author{
${ }^{* 1}$ Marlina, ${ }^{1}$ Lukman Hakim, ${ }^{2}$ Efendi \\ ${ }^{1}$ Jurusan Proteksi Tanaman Fakultas Pertanian Unsyiah \\ ${ }^{2}$ Jurusan Agroteknologi Fakultas Pertanian Unsyiah \\ Jl. Tgk Hasan Krueng Kalee No. 3 Banda Aceh Kopelma Darussalam \\ ${ }^{* 1}$ e-mail korespondensi : marlina.fpunsyiah@gmail.com
}

\begin{abstract}
Bacterial Leaf Blight (HDB) caused by the bacteria Xanthomonas oryzae pv. oryzae (Xoo) is the most dangerous disease that can reduce rice production by around 15-80\%. The control method considered to be the most effective so far is planting resistant varieties. The aim of this study was to evaluate the resistance of several lines of radiation mutation from Aceh's local rice against bacterial leaf blight (Xanthomonas oryzae pv. Oryzae). Experiments were carried out in the Greenhouse at the Experimental Garden of the Faculty of Agriculture, the Laboratory of Seed Technology for the Agrotechnology Study Program, the Laboratory for Plant Disease Science for the Study Program of Plant Protection, Faculty of Agriculture, and the Biology Laboratory at the Faculty of Teacher Training and Education, Syiah Kuala University, Banda Aceh. The study lasted for 5 months from July to November 2017. This study used a one-factor randomized block design (RBD) with 3 replications. The treatment factors tested were the Mutation Result Line, namely: Simeulu (USK-Snbr-M04-238-074001), Sisambay (USK-Snbr-M04-238-081-002), Sanberasi (USK-Snbr-M04-238) -017-023), Siteluk (USK-Snbr-M04-238-092097), Sibahak (USK-Snbr-M04-238-073-079), Sulutan Unsrat-1, Sibabus (USK-Snbr-M04-238 -110-116), Simuara (USK-SnbrM04-238-091-097B), Siluan (USK-Snbr-M04-238-058-064), Sikuala (USK-Snbr-M04-238-114-120), UF5, Sibuluh (USK-SnbrM04-238-V1B-017), Sialavan (USK-Snbr-M04-238-051-057E), Snb, UF 1, IRBB, 118- (Snbr-238-112-118-180-11), 119- (Snbr238-112-119-160-10). There are 54 experimental units and each experimental unit consists of 2 plant units, one plant as the sample plant. The variables observed included the incubation period of the disease, the length of the lesion, and the intensity of the disease. Based on the test results on 18 lines resulting from the mutation of Aceh local rice radiation against bacterial leaf blight, it shows that there is no difference in the length of the incubation period between the lines. The length of the lesions between lines was significantly different at measurements 7, 14 and 21 days after the inclusion of blight. Based on the length of the lesio, all lines were categorized as resistant, but the intensity of the disease increased with increasing age of the rice plants in the tested lines which changed the resistance level from very resistant and resistant to a category that was mildly susceptible and somewhat resistant.
\end{abstract}

Keywords: Aceh local rice, bacterial leaf blight, radiation mutation

\begin{abstract}
Abstrak. Penyakit Hawar Daun Bakteri (HDB) yang disebabkan oleh bakteri Xanthomonas oryzae pv. oryzae (Xoo) merupakan penyakit paling berbahaya yang dapat menekan produksi padi sekitar 15-80\%. Cara pengendalian yang dianggap paling efektif sejauh ini adalah penanaman varietas tahan. Penelitian bertujuan untuk mengevaluasi ketahanan beberapa galur hasil mutasi radiasi padi lokal Aceh terhadap penyakit hawar daun bakteri (Xanthomonas oryzae pv. oryzae). Percobaan dilakukan dalam Rumah Kaca di Kebun Percobaan Fakultas Pertanian, Laboratorium Teknologi Benih Program Studi Agroteknologi, Laboratorium Ilmu Penyakit Tumbuhan Program Studi Proteksi Tanaman Fakultas Pertanian, dan Laboratorium Biologi Fakultas Keguruan dan Ilmu Pendidikan Universitas Syiah Kuala Banda Aceh. Penelitian berlangsung selama 5 bulan dari bulan Juli sampai dengan November 2017. Penelitian ini menggunakan Rancangan Acak Kelompok (RAK) satu faktor dengan 3 ulangan. Faktor perlakuan yang dicobakan adalah Galur Hasil Mutasi, yakni : Simeulu (USK-Snbr-M04-238-074-001), Sisambay (USK-Snbr-M04-238-081-002), Sanberasi (USK-Snbr-M04-238-017-023), Siteluk (USK-Snbr-M04-238-092-097), Sibahak (USK-Snbr-M04-238-073-079), Sulutan Unsrat-1, Sibabus (USK-Snbr-M04-238-110-116), Simuara (USK-Snbr-M04238-091-097B), Siluan (USK-Snbr-M04-238-058-064), Sikuala (USK-Snbr-M04-238-114-120), UF5, Sibuluh (USK-SnbrM04-238-V1B-017), Sialavan (USK-Snbr-M04-238-051-057E), Snb, UF 1, IRBB, 118-(Snbr-238-112-118-180-11), 119-(Snbr238-112-119-160-10). Terdapat 54 satuan percobaan dan setiap satuan percobaan terdiri dari 2 unit tanaman, satu tanaman sebagai tanaman sampel. Peubah yang diamati meliputi masa inkubasi penyakit, panjang lesio, intensitas penyakit. Berdasarkan hasil uji terhadap 18 galur hasil mutasi radiasi padi lokal Aceh terhadap penyakit hawar daun bakteri menunjukkan bahwa tidak terdapat perbedaan lamanya masa inkubasi antar galur. Panjang lesio antar galur terdapat perbedaan yang signifikan pada pengukuran 7, 14 dan 21 hari setelah inkulasi penyakit hawar daun. Berdasarkan ukuran panjang lesio, semua galur tergolong kategori tahan, akan tetapi intensitas penyakit semakin meningkat seiring bertambahnya umur tanaman padi pada galur-galur yang diuji yang mengubah tingkat ketahanan dari sangat tahan dan tahan menjadi kategori agak rentan dan agak tahan.
\end{abstract}

Kata kunci: hawar daun bakteri, mutasi radiasi, padi lokal Aceh 


\section{PENDAHULUAN}

Padi merupakan sumber makanan pokok terpenting di Indonesia. Terdapat sebanyak $95 \%$ penduduk Indonesia mengkonsumsi beras sebagai makanan pokoknya (Norsalis, 2011). Salah satu tantangan besar yang dihadapi untuk memenuhi kebutuhan akan pangan beras di Indonesia adalah ancaman yang timbul dari gangguan patogen penyebab penyakit tanaman dalam budidaya padi. Penyakit Hawar Daun Bakteri (HDB) yang disebabkan oleh bakteri Xanthomonas oryzae pv. oryzae (Xoo) merupakan satu diantara penyakit paling berbahaya yang dapat menekan produksi padi sekitar 15-80\%, bergantung pada stadia mana tanaman padi terserang (Lalitha $d k k$., 2010).

Pada daerah-daerah tropis seperti Indonesia cukup banyak dijumpai strain patogen HDB. Dilaporkan pertama kali adanya serangan HDB di Indonesia pada tahun 1950. Hingga saat ini telah diidentifikasi sebanyak 12 strain Xoo dengan tingkat virulensi yang berbeda. Strain yang paling dominan menyerang tanaman padi yakni strain IV dan VIII (Suparyono $d k k$., 2004). Perubahan iklim juga menyebabkan patotipe bakteri tersebut terus bertambah yang berdampak terhadap ketahanan tanaman padi di lapangan. Pengendaliannya menjadi sulit karena munculnya patotipe baru yang lebih virulen. Pemuliaan tanaman padi untuk memperoleh sifat tahan HDB perlu terus dilakukan seiring dengan perkembangan patotipe patogen (Wening $d k k ., 2016$ ).

Pemuliaan tanaman adalah kegiatan mengubah susunan genetik individu maupun populasi tanaman untuk suatu tujuan sehingga diperoleh tanaman yang lebih bermanfaat. Mengubah susunan genetik individu maupun populasi tanaman dapat dilakukan antara lain dengan mutasi genetik. Mutasi genetik tanaman dapat diinduksi menggunakan mutagen seperti radiasi sinar gamma. Bagian tanaman yang diradiasi biasanya adalah benih yang akan ditumbuhkan atau bagian tanaman lainnya yang dapat ditumbuhkan. Pemuliaan tanaman secara mutasi disebut pemuliaan mutasi. Pemuliaan mutasi mempunyai karakter spesifik antara lain sangat efektif untuk mengubah sedikit sifat dalam perbaikan varietas tanaman (Advertorial BATAN, 2013).

Dilaporkan bahwa radiasi sinar gamma dapat menginduksi dan meningkatkan nutrisi pada padi, sehingga dapat memperbaiki kualitas beras dan beberapa sifat agronomis serta terjadinya peningkatan asam amino total, antioksidan, dan klorofil pada mutan padi yang telah diradiasikan dengan sinar gamma (Song $d k k$., 2012). Melalui pemuliaan mutasi, dinilai sebagai cara yang efektif menghasilkan varietas-varietas padi yang tahan terhadap penyakit HDB. Pemilihan varietas yang didasarkan pada komposisi patotipe HDB di wilayah target lebih efektif sebagai komponen pengendalian (Sudir $d k k ., 2012$ ).

Untuk mengevaluasi ketahanan beberapa galur hasil mutasi radiasi padi lokal Aceh terhadap penyakit hawar daun bakteri (Xanthomonas oryzae pv. oryzae), maka perlu dilakukan penelitian.

\section{Tempat dan Waktu Penelitian}

\section{METODE PENELITIAN}

Percobaan dilakukan dalam Rumah Kaca di Kebun Percobaan Fakultas Pertanian, Laboratorium Teknologi Benih Program Studi Agroteknologi, Laboratorium Ilmu Penyakit Tumbuhan Program Studi Proteksi Tanaman Fakultas Pertanian, dan Laboratorium Biologi Fakultas Keguruan dan Ilmu Pendidikan Universitas Syiah Kuala Banda Aceh. Penelitian berlangsung mulai bulan Juli sampai bulan November 2017.

\section{Alat dan Bahan}

Alat yang digunakan dalam penelitian ini adalah cangkul, pot ukuran $14 \mathrm{~kg}$, timbangan analitik, petridish, tabung reaksi, autoclave, erlenmeyer, pinset, jarum ose, micro pipet, inkubator, spektrofotometer, kertas label, kertas buram, spidol permanen, meteran, penggaris dan moisture meter.

Bahan yang digunakan dalam penelitian ini adalah benih padi hasil mutasi radiasi antara lain yaitu : Simeulu (USK-Snbr-M04-238-074-001), Sisambay (USK-Snbr-M04-238-081-002), Sanberasi (USK-Snbr-M04-238-017023), Siteluk (USK-Snbr-M04-238-092-097), Sibahak (USK-Snbr-M04-238-073-079), Sulutan Unsrat-1, Sibabus (USK-Snbr-M04-238-110-116), Simuara (USK-Snbr-M04-238-091-097B), Siluan (USK-Snbr-M04-238-058-064), Sikuala (USK-Snbr-M04-238-114-120, UF5, Sibuluh (USK-Snbr-M04-238-V1B-017), Sialavan (USK-Snbr-M04238-051-057E), Snb, UF 1, IRBB, 118-(Snbr-238-112-118-180-11), 119-(Snbr-238-112-119-160-10). Inokulum bakteri Xanthomonas oryzae pv. oryzae, NA, aquades, tanah, pupuk kandang, pupuk Urea, KCl, SP-36, dan air.

\section{Rancangan Percobaan}

Penataan satuan percobaan di lapangan disusun menurut Rancangan Acak Kelompok (RAK) pola satu faktor yang terdiri dari 18 perlakuan. Setiap perlakuan diulang sebanyak 3 kali, sehingga terdapat 54 satuan percobaan. Setiap satuan percobaan diambil 2 rumpun padi sebagai tanaman sampel sehingga total sampel sebanyak 108 rumpun. Perlakuan yang dicobakan merupakan galur-galur mutan padi lokal Aceh sebagai berikut: 
Marlina, Lukman Hakim, dan Efendi. Uji Ketahanan Beberapa Galur Padi Smart Hasil Mutasi Radiasi Padi Lokal Aceh Dengan Teknologi Sinar Gamma Terhadap Penyakit Hawar Daun Bakteri (Xanthomonas oryzae pv. oryzae)

Tabel 1. Susunan perlakuan

\begin{tabular}{cl}
\hline No & \multicolumn{1}{c}{ Nama Mutan } \\
\hline 1 & Simeulu (USK-Snbr-M04-238-074-001) \\
2 & Sisambay (USK-Snbr-M04-238-081-002) \\
3 & Sanberasi (USK-Snbr-M04-238-017-023) \\
4 & Siteluk (USK-Snbr-M04-238-092-097) \\
5 & Sibahak (USK-Snbr-M04-238-073-079) \\
6 & Sulutan Unsrat-1 \\
7 & Sibabus (USK-Snbr-M04-238-110-116) \\
8 & Simuara (USK-Snbr-M04-238-091-097B) \\
9 & Siluan (USK-Snbr-M04-238-058-064) \\
10 & Sikuala (USK-Snbr-M04-238-114-120) \\
11 & UF5 \\
12 & Sibuluh (USK-Snbr-M04-238-V1B-017) \\
13 & Sialavan (USK-Snbr-M04-238-051-057E) \\
14 & Snb \\
15 & UF 1 \\
16 & IRBB \\
17 & $118-($ Snbr-238-112-118-180-11) \\
18 & $119-($ Snbr-238-112-119-160-10) \\
\hline
\end{tabular}

\section{Pelaksanaan Penelitian \\ Persiapan Semai}

Benih padi direndam dengan air selama 24 jam, kemudian benih dikecambahkan pada botol yang telah dilapisi dengan tissu basah. Setelah radikula muncul, benih sudah siap disemai. Penyemaian dilakukan di dalam tray yang berisi tanah dan pupuk kandang dengan perbandingan $2: 1$. Benih yang disemai sebanyak 60 benih pada masing-masing tray perlakuan.

\section{Penanaman}

Setelah bibit berumur 10 hari di persemaian, dipindahtanamkan ke masing-masing pot perlakuan yang telah dipersiapkan sebelumnya. Media tanam dalam penelitian ini menggunakan tanah yang dicampur dengan pupuk kandang dengan perbandingan 2:1, kemudian dicampur dengan air dan diaduk sampai rata sehingga membentuk tekstur lumpur. Kedalaman bibit padi yang ditanam berkisar $2 \mathrm{~cm}$. Dosis pupuk rekomendasi yang digunakan adalah $250 \mathrm{~kg} / \mathrm{ha}$ Urea, $50 \mathrm{~kg} / \mathrm{ha} \mathrm{SP}-36$, dan $75 \mathrm{~kg} / \mathrm{ha} \mathrm{KCl}$. Pemupukan dilakukan tiga tahap pemberian. Tahap pertama diberikan saat awal penanaman yaitu pupuk Urea, SP-36 dan $\mathrm{KCl}$. Tahap kedua pemberian pupuk Urea pada saat umur tanaman padi 15 HST (hari setelah tanam). Tahap ketiga yaitu pemberian pupuk Urea pada saat umur 30 HST.

\section{Isolasi Xanthomonas oryzae pv. oryzae}

Sumber inokulum Xoo diperoleh dari tanaman padi yang terinfeksi di Kebun Percobaan Fakultas Pertanian, Universitas Syiah Kuala, Banda Aceh. Daun tanaman padi yang terinfeksi digunting dan dibersihkan terlebih dahulu dengan air aquades. Kemudian daun tersebut digunting lagi dengan ukuran $0,5 \mathrm{~cm}$ x $0,5 \mathrm{~cm}$ dan disteril dengan cara direndam di dalam alkohol $70 \%$ selama 2 menit lalu dimasukkan ke dalam air aquades. Selanjutnya daun ditiriskan di atas tissu agar air meresap.

Potongan daun yang sudah steril kemudian ditanam di atas media NA (5 g NA+250 ml aquades) dalam petridish yang sudah dipersiapkan sebelumnya. Selanjutnya diinkubasi selama 3x24 jam. Setelah 3x24 jam koloni bakteri tumbuh diisolasi kembali agar diperoleh biakan murni. Biakan murni yang telah tumbuh diambil dengan menggunakan jarum ose streril dan dipindahkan ke media miring tabung reaksi, pembiakan dilakukan selama $2 \times 24$ jam.

\section{Inokulasi Xanthomonas oryzae pv. oryzae}

Padi yang berumur 42 HST atau memasuki fase vegetatif aktif diinokulasi dengan inokulum Xoo dengan metode Leaf Cipping (Herlina dan Silitonga, 2011) yaitu melukai daun dengan memotong secara melintang menggunakan gunting steril sepanjang $5 \mathrm{~cm}$ dari ujung daun. Selanjutnya ujung daun yang telah dipotong kemudian dirunduk dan dicelupkan ke dalam suspensi bakteri Xoo dengan kerapatan $10^{8} \mathrm{sel} \mathrm{ml}^{-1}$. Panjang daun yang 
Marlina, Lukman Hakim, dan Efendi. Uji Ketahanan Beberapa Galur Padi Smart Hasil Mutasi Radiasi Padi Lokal Aceh Dengan Teknologi Sinar Gamma Terhadap Penyakit Hawar Daun Bakteri (Xanthomonas oryzae pv. oryzae)

dicelupkan yaitu $2 \mathrm{~cm}$. Proses perhitungan kerapatan bakteri Xoo dilakukan di Laboratorium Biologi Fakultas Keguruan dan Ilmu Pendidikan, Universitas Syiah Kuala dengan menggunakan alat Spektrofotometer.

\section{Peubah respon}

Beberapa peubah respon yang diamati dalam penelitian ini meliputi:

1. Masa Inkubasi

Masa inkubasi dihitung pada saat setelah inokulasi sampai dengan munculnya gejala serangan yang ditimbulkan oleh $X o o$, ditandai dengan warna daun menguning dan kering pada bagian ujung daun yang digunting.

2. Panjang Lesio Daun

Pengamatan panjang lesio daun dilakukan pada 7, 14 dan 21 hari setelah inokulasi (HSI) dengan cara mengukur panjang gejala $(\mathrm{cm})$ yang ditimbulkan oleh Xoo pada daun yang telah dilukai.Tanaman dikategorikan tahan atau rentan berdasarkan panjang lesio daun: jika panjang lesio $<3 \mathrm{~cm}$ Tahan (T), 3-6 $\mathrm{cm}$ Agak Tahan (AT), dan $>6$ cm Rentan (R) (Chen $d k k$., 2003).

3. Intensitas Penyakit

Pengamatan intensitas penyakit juga dilakukan pada 7, 14 dan 21 HSI dengan cara mengukur panjang lesio daun dibandingkan dengan panjang daun keseluruhan $(\mathrm{cm})$. Perhitungan intensitas penyakit menggunakan rumus:

$$
\mathrm{IP}=(\text { Panjang Lesio/Total Panjang Daun }) \times 100 \%
$$

Ketahanan tanaman padi terhadap penyakit hawar daun bakteri, diukur berdasarkan intensitas penyakit kemudian dimasukkan ke dalam Sistem Evaluasi Standar (IRRI,2014) sebagai berikut :

Tabel 2. Kriteria Ketahanan Galur/Varietas Padi Terhadap Penyakit Hawar Daun Bakteri

\begin{tabular}{ccc}
\hline Skala & Intensitas Penyakit & Kategori Ketahanan \\
\hline 1 & $0-3 \%$ & Sangat Tahan (ST) \\
2 & $4-6 \%$ & Tahan (T) \\
3 & $7-12 \%$ & Agak Tahan (AT) \\
4 & $13-25 \%$ & Agak Rentan (AR) \\
5 & $26-75 \%$ & Rentan (R) \\
6 & $76-100 \%$ & Sangat Rentan (SR) \\
\hline
\end{tabular}

\section{Analisis Data}

Data hasil pengamatan dianalisis dengan uji-F. Jika hasil sidik ragam terdapat pengaruh perlakuan secara nyata pada taraf $\alpha_{0,05}$, maka dilakukan uji lanjutan untuk mengetahui perbedaan antar perlakuan dengan menggunakan prosedur uji Beda Nyata Terkecil (BNT) pada taraf $\alpha_{0,05 .}$.

\section{Masa Inkubasi}

\section{HASIL DAN PEMBAHASAN}

Hasil penelitian menunjukkan bahwa pengaruh bakteri hawar daun (Xanthomonas oryzae pv. oryzae) pada galur mutan yang diuji tidak memperlihatkan adanya perbedaan yang signifikan terhadap masa inkubasi. Rata-rata masa inkubasi penyakit hawar daun bakteri pada beberapa galur padi hasil mutasi radiasi dapat dilihat pada Tabel 3 .

Tabel 3. Masa Inkubasi Penyakit Hawar Daun Bakteri Pada Galur Hasil Mutasi Radiasi

\begin{tabular}{lc}
\multicolumn{1}{c}{ Nama Mutan } & Masa Inkubasi (hari) \\
\hline Simeulu (USK-Snbr-M04-238-074-001) & 2,33 \\
Sisambay (USK-Snbr-M04-238-081-002) & 1,33 \\
Sanberasi (USK-Snbr-M04-238-017-023) & 2,67 \\
Siteluk (USK-Snbr-M04-238-092-097) & 2,33 \\
Sibahak (USK-Snbr-M04-238-073-079) & 1,33 \\
Sulutan Unsrat-1 & 2,67 \\
Sibabus (USK-Snbr-M04-238-110-116) & 2,00 \\
Simuara (USK-Snbr-M04-238-091-097B) & 1,67 \\
Siluan (USK-Snbr-M04-238-058-064) & 2,33 \\
Sikuala (USK-Snbr-M04-238-114-120) & 2,67 \\
UF5 & 1,67 \\
Sibuluh (USK-Snbr-M04-238-V1B-017) & 2,33 \\
Sialavan (USK-Snbr-M04-238-051-057E) & 1,33 \\
Snb & 2,00 \\
UF 1 & 1,67 \\
IRBB & 3,00 \\
118-(Snbr-238-112-118-180-11) & 2,33 \\
119-(Snbr-238-112-119-160-10) & 2,33 \\
\hline
\end{tabular}


Tabel 3 menunjukkan bahwa masa inkubasi penyakit HDB antar galur memiliki perbedaan yang tidak signifikan. Hal ini menunjukkan bahwa galur mutan yang diuji mempunyai tingkat kepekaan yang sama. Gejala serangan yang timbul pada antar galur yang diuji berada pada kisaran jangka waktu yang hampir sama.

\section{Panjang Lesio}

Bakteri Xanthomonas oryzae pv. oryzae mempengaruhi panjang lesio pada daun galur padi hasil mutasi radiasi padi lokal Aceh pada umur 7, 14 dan 21 hari setelah inokulasi (HSI) . Rata-rata panjang lesio daun beberapa galur padi hasil mutasi radiasi dapat dilihat pada Tabel 4.

Tabel 4. Panjang Lesio Daun Akibat Bakteri Xanthomonas oryzae pv. oryzae 7, 14 dan 21 HSI Pada Beberapa Galur Hasil Mutasi Radiasi

\begin{tabular}{lccc}
\hline \multicolumn{1}{c}{ Jenis Mutan } & \multicolumn{3}{c}{ Panjang Lesio (cm) } \\
\cline { 2 - 4 } Simeulu (USK-Snbr-M04-238-074-001) & $7 \mathrm{HSI}$ & $14 \mathrm{HSI}$ & $1,93 \mathrm{ab}$ \\
Sisambay (USK-Snbr-M04-238-081-002) & $0,60 \mathrm{ab}$ & $1,13 \mathrm{ab}$ & $2,07 \mathrm{~b}$ \\
Sanberasi (USK-Snbr-M04-238-017-023) & $0,85 \mathrm{~b}$ & $1,21 \mathrm{~b}$ & $1,09 \mathrm{~b}$ \\
Siteluk (USK-Snbr-M04-238-092-097) & $0,62 \mathrm{ab}$ & $1,14 \mathrm{ab}$ & $1,99 \mathrm{~b}$ \\
Sibahak (USK-Snbr-M04-238-073-079) & $0,57 \mathrm{ab}$ & $1,05 \mathrm{ab}$ & $2,08 \mathrm{~b}$ \\
Sulutan Unsrat-1 & $0,98 \mathrm{bc}$ & $1,34 \mathrm{bc}$ & $1,99 \mathrm{~b}$ \\
Sibabus (USK-Snbr-M04-238-110-116) & $0,63 \mathrm{ab}$ & $1,07 \mathrm{ab}$ & $2,00 \mathrm{~b}$ \\
Simuara (USK-Snbr-M04-238-091-097B) & $0,66 \mathrm{ab}$ & $1,16 \mathrm{ab}$ & $1,80 \mathrm{ab}$ \\
Siluan (USK-Snbr-M04-238-058-064) & $0,58 \mathrm{ab}$ & $0,91 \mathrm{ab}$ & $2,05 \mathrm{~b}$ \\
Sikuala (USK-Snbr-M04-238-114-120) & $0,86 \mathrm{~b}$ & $1,34 \mathrm{bc}$ & $2,24 \mathrm{~b}$ \\
UF5 & $0,93 \mathrm{ab}$ & $1,33 \mathrm{bc}$ & $1,98 \mathrm{~b}$ \\
Sibuluh (USK-Snbr-M04-238-V1B-017) & $0,80 \mathrm{~b}$ & $1,12 \mathrm{ab}$ & $1,73 \mathrm{ab}$ \\
Sialavan (USK-Snbr-M04-238-051-057E) & $0,60 \mathrm{ab}$ & $0,87 \mathrm{a}$ & $2,57 \mathrm{c}$ \\
Snb & $1,18 \mathrm{c}$ & $1,61 \mathrm{c}$ & $2,11 \mathrm{~b}$ \\
UF 1 & $0,68 \mathrm{ab}$ & $1,15 \mathrm{ab}$ & $1,03 \mathrm{~b}$ \\
IRBB & $0,79 \mathrm{~b}$ & $1,16 \mathrm{ab}$ & $1,92 \mathrm{ab}$ \\
118-(Snbr-238-112-118-180-11) & $0,44 \mathrm{a}$ & $0,86 \mathrm{a}$ & $2,27 \mathrm{bc}$ \\
119-(Snbr-238-112-119-160-10) & $0,76 \mathrm{~b}$ & $1,14 \mathrm{ab}$ & $1,24 \mathrm{~b}$ \\
\hline Keterangan
\end{tabular}

Keterangan : Angka yang diikuti oleh huruf yang sama pada kolom yang sama berbeda tidak nyata pada taraf $\alpha_{0,05}(\mathrm{BNT})$

Berdasarkan hasil pengukuran terhadap panjang lesio, beberapa galur padi hasil mutasi radiasi menunjukkan reaksi yang berbeda terhadap bakteri hawar daun (Xanthomonas oryzae pv. oryzae). Pada penelitian yang pernah dilakukan Suparyono $d k k$., (2004), galur padi IRBB termasuk jenis padi yang tahan terhadap serangan HDB. Tampak dari Tabel 4, bahwa banyak galur-galur lain yang memiliki tingkat ketahanan yang sama dengan galur IRBB. Menurut Liu $d k k .,(2006)$, bahwa gen ketahanan terhadap ras Xanthomonas oryzae pv. oryzae dikendalikan oleh gen R mayor dan suatu tanaman akan menjadi tahan karena tanaman tersebut menghasilkan fitoaleksin sebagai hasil interaksi inang patogen yang berfungsi untuk menghambat perkembangan bakteri.

Jika mengacu pada ukuran tingkat ketahanan yang dikemukakan Chen $d k k$.,(2003), panjang lesio kurang dari $3 \mathrm{~cm}$ termasuk kategori tahan, antara 3-6 cm digolongkan sebagai agak tahan dan melebihi panjang $6 \mathrm{~cm}$ berarti rentan. Dalam hal ini semua galur yang diuji memiliki sifat tahan terhadap HBD karena panjang lesio kurang dari 3 $\mathrm{cm}$. Hal ini diduga karena galur padi yang telah diradiasi sinar gamma tesebut memiliki kandungan genetik yang tahan terhadap serangan bakteri Xanthomonas oryzae pv. oryzae

Resistensi suatu tanaman terhadap patogen tertentu dapat disebabkan oleh beberapa hal, seperti tanaman tersebut bukan merupakan inang bagi patogen (nonhost resistensi) kemudian tanaman tersebut memiliki gen resisten terhadap patogen (R gene) antara lain berupa resistensi murni, resistesi spesifik ras, resistensi spesifik kultivar, atau resisten gen ke gen, dan yang terakhir karena tanaman tersebut toleran terhadap patogen tersebut atau disebut juga tanaman escape (Agrios, 2005).

\section{Intensitas Penyakit}

Hasil penelitian menunjukkan bahwa galur hasil mutasi radiasi padi lokal Aceh berpengaruh sangat nyata terhadap intensitas penyakit hawar daun bakteri yang disebabkan oleh bakteri Xanthomonas oryzae pv. oryzae pada 7, 14, dan 21 HSI. Intensitas penyakit hawar daun bakteri dapat dilihat pada Tabel 5. 
Marlina, Lukman Hakim, dan Efendi. Uji Ketahanan Beberapa Galur Padi Smart Hasil Mutasi Radiasi Padi Lokal Aceh Dengan Teknologi Sinar Gamma Terhadap Penyakit Hawar Daun Bakteri (Xanthomonas oryzae pv. oryzae)

Tabel 5. Intensitas Serangan Penyakit Hawar Daun Bakteri (Xanthomonas oryzae pv. oryzae) Terhadap Beberapa Galur Hasil Mutasi Radiasi Padi Lokal Aceh.

\begin{tabular}{lccc}
\hline \multicolumn{1}{c}{ Jenis Mutan } & \multicolumn{3}{c}{ Panjang Lesio (cm) } \\
\cline { 2 - 4 } Simeulu (USK-Snbr-M04-238-074-001) & $7 \mathrm{HSI}$ & $14 \mathrm{HSI}$ & $21 \mathrm{HSI}$ \\
Sisambay (USK-Snbr-M04-238-081-002) & $2,09 \mathrm{ab}$ & $10,37 \mathrm{ab}$ & $13,03 \mathrm{ab}$ \\
Sanberasi (USK-Snbr-M04-238-017-023) & $1,86 \mathrm{ab}$ & $8,78 \mathrm{ab}$ & $11,21 \mathrm{ab}$ \\
Siteluk (USK-Snbr-M04-238-092-097) & $1,72 \mathrm{ab}$ & $9,45 \mathrm{ab}$ & $12,35 \mathrm{ab}$ \\
Sibahak (USK-Snbr-M04-238-073-079) & $1,32 \mathrm{a}$ & $8,33 \mathrm{ab}$ & $11,16 \mathrm{ab}$ \\
Sulutan Unsrat-1 & $3,51 \mathrm{~b}$ & $11,46 \mathrm{~b}$ & $13,61 \mathrm{~b}$ \\
Sibabus (USK-Snbr-M04-238-110-116) & $1,87 \mathrm{ab}$ & $9,43 \mathrm{ab}$ & $12,40 \mathrm{ab}$ \\
Simuara (USK-Snbr-M04-238-091-097B) & $1,78 \mathrm{ab}$ & $9,47 \mathrm{ab}$ & $12,05 \mathrm{ab}$ \\
Siluan (USK-Snbr-M04-238-058-064) & $1,33 \mathrm{ab}$ & $7,78 \mathrm{ab}$ & $10,63 \mathrm{ab}$ \\
Sikuala (USK-Snbr-M04-238-114-120) & $3,02 \mathrm{~b}$ & $11,39 \mathrm{~b}$ & $13,47 \mathrm{~b}$ \\
UF5 & $2,46 \mathrm{ab}$ & $10,02 \mathrm{ab}$ & $12,58 \mathrm{ab}$ \\
Sibuluh (USK-Snbr-M04-238-V1B-017) & $3,09 \mathrm{~b}$ & $10,83 \mathrm{~b}$ & $13,73 \mathrm{~b}$ \\
Sialavan (USK-Snbr-M04-238-051-057E) & $2,60 \mathrm{ab}$ & $9,82 \mathrm{ab}$ & $13,44 \mathrm{~b}$ \\
Snb & $7,66 \mathrm{c}$ & $15,64 \mathrm{c}$ & $18,41 \mathrm{c}$ \\
UF 1 & $2,63 \mathrm{ab}$ & $10,94 \mathrm{~b}$ & $14,17 \mathrm{~b}$ \\
IRBB & $2,60 \mathrm{ab}$ & $10,33 \mathrm{ab}$ & $13,07 \mathrm{ab}$ \\
118-(Snbr-238-112-118-180-11) & $2,15 \mathrm{ab}$ & $10,21 \mathrm{ab}$ & $12,73 \mathrm{ab}$ \\
119-(Snbr-238-112-119-160-10) & $1,98 \mathrm{ab}$ & $6,14 \mathrm{a}$ & $7,95 \mathrm{a}$ \\
\hline
\end{tabular}

Keterangan : Angka yang diikuti oleh huruf yang sama pada kolom yang sama berbeda tidak nyata pada taraf $\alpha_{0,05}(\mathrm{BNT})$

Tabel 5 menunjukkan bahwa terdapat perbedaan intensitas penyakit antar galur padi hasil mutasi radiasi sinar gamma padi lokal Aceh pada 7, 14, dan 21 HSI. Selain itu terlihat kecenderungan bahwa semakin bertambah umur tanaman padi, intensitas penyakit juga semakin meningkat. Perbedaan tingkat intensitas penyakit antar galur yang diuji tergolong dalam kelompok sangat tahan, tahan, agak tahan dan agak rentan.

Perbedaan nilai intensitas penyakit bakteri hawar daun tersebut menunjukkan tingkat ketahanan dari setiap galur padi yang diamati berbeda. Ketahanan suatu varietas padi dapat dikategorikan berdasarkan intensitas penyakit (IRRI, 2014). Sebagaimana disajikan pada Tabel 6, ketahanan varietas padi hasil mutasi radiasi terhadap penyakit bakteri hawar daun cukup beragam bila dikelompokkan berdasarkan intensitas penyakit.

Tabel 6. Ketahanan Beberapa Galur Hasil Mutasi Radiasi terhadap Penyakit Hawar Daun Bakteri (Xanthomonas oryzae pv. oryzae) berdasarkan Sistem Evaluasi Standar (IRRI, 2014)

\begin{tabular}{|c|c|c|c|c|c|c|}
\hline \multirow{2}{*}{ Jenis Mutan } & \multicolumn{6}{|c|}{ Sistem Evaluasi Standar } \\
\hline & $7 \mathrm{HSI}$ & Ket. & 14 HSI & Ket. & $21 \mathrm{HSI}$ & Ket. \\
\hline Simeulu (USK-Snbr-M04-238-074-001) & 2,09 & ST & 10,37 & AT & 13,03 & AR \\
\hline Sisambay (USK-Snbr-M04-238-081-002) & 1,86 & ST & 8,78 & AT & 11,21 & AT \\
\hline Sanberasi (USK-Snbr-M04-238-017-023) & 1,72 & ST & 9,45 & AT & 12,35 & AT \\
\hline Siteluk (USK-Snbr-M04-238-092-097) & 1,32 & ST & 8,33 & AT & 11,16 & AT \\
\hline Sibahak (USK-Snbr-M04-238-073-079) & 3,51 & $\mathrm{~T}$ & 11,46 & AT & 13,61 & AR \\
\hline Sulutan Unsrat-1 & 1,87 & ST & 9,43 & AT & 12,40 & AT \\
\hline Sibabus (USK-Snbr-M04-238-110-116) & 1,78 & ST & 9,47 & AT & 12,05 & AT \\
\hline Simuara (USK-Snbr-M04-238-091-097B) & 1,33 & ST & 7,78 & AT & 10,63 & AT \\
\hline Siluan (USK-Snbr-M04-238-058-064) & 3,02 & $\mathrm{~T}$ & 11,39 & AT & 13,47 & AR \\
\hline Sikuala (USK-Snbr-M04-238-114-120) & 2,46 & ST & 10,02 & AT & 12,58 & AT \\
\hline UF5 & 3,09 & $\mathrm{~T}$ & 10,83 & AT & 13,73 & AR \\
\hline Sibuluh (USK-Snbr-M04-238-V1B-017) & 2,60 & ST & 9,82 & AT & 13,44 & AR \\
\hline Sialavan (USK-Snbr-M04-238-051-057E) & 7,66 & ST & 15,64 & AT & 18,41 & AR \\
\hline Snb & 2,63 & ST & 10,94 & AT & 14,17 & AR \\
\hline UF 1 & 2,60 & ST & 10,33 & AT & 13,07 & AR \\
\hline IRBB & 2,15 & ST & 10,21 & AT & 12,73 & AT \\
\hline 118-(Snbr-238-112-118-180-11) & 1,98 & ST & 6,14 & $\mathrm{~T}$ & 7,95 & AT \\
\hline 119-(Snbr-238-112-119-160-10) & 1,96 & ST & 6,48 & $\mathrm{~T}$ & 8,24 & AT \\
\hline
\end{tabular}

Keterangan : ST (sangat tahan) 0-3\%, T (tahan) 4-6\%, AT (agak tahan) 7-12\%, AR (agak rentan) 13-25\% (IRRI, 2014) 
Kondisi intensitas penyakit pada saat 7 HSI, tingkat ketahanan galur padi yang diuji berada pada kategori sangat tahan dan tahan. Setelah 21 HIS, galur-galur yang awalnya bersifat tahan dan sangat tahan, mengalami perubahan menjadi agak rentan dan agak tahan. Jadi tidak ada satu pun diantara galur yang diuji mampu bertahan dari serangan penyakit HDB.

Menurut Abadi (2003), keragaman tingkat ketahanan dan kepekaan terhadap patogen diantara varietas tanaman disebabkan oleh gen ketahanan yang berbeda dalam setiap galur dan juga gen yang memberikan virulensi terhadap patogen berkaitan dengan ketahanan dalam inang dan sebaliknnya. Sesuai dengan hasil penelitian Anggraini, $d k k .$, (2013) yang menyatakan bahwa suatu varietas padi yang memiliki sifat tahan terhadap Xoo dapat berubah menjadi rentan karena patah ketahanannya.

Menurut Suryadi dan Kadir (2008), tingkat virulensi patogen sangat dipengaruhi oleh ketahanan tanaman terhadap patogen baik genetik maupun kandungan nutrisi yang akan mempengaruhi perkembangan patogen. Faktor yang mempengaruhi perubahan varietas tahan menjadi tidak tahan yaitu karena kecepatan parubahan ketahanan, pola tanam dan komposisi varietas dengan kandungan genetis yang berbeda, ditanam dalam waktu dan hamparan tertentu (Ogawa, 1993).

\section{KESIMPULAN}

Berdasarkan hasil uji terhadap 18 galur hasil mutasi radiasi padi lokal Aceh terhadap penyakit hawar daun bakteri menunjukkan bahwa tidak terdapat perbedaan lamanya masa inkubasi antar galur. Panjang lesio antar galur terdapat perbedaan yang signifikan pada pengukuran 7, 14 dan 21 hari setelah inkulasi penyakit hawar daun. Berdasarkan ukuran panjang lesio, semua galur tergolong kategori tahan, akan tetapi intensitas penyakit semakin meningkat seiring bertambahnya umur tanaman padi pada galur-galur yang diuji yang mengubah tingkat katahanan dari sangat tahan dan tahan menjadi kategori agak rentan dan agak tahan. Tidak ada galur hasil mutasi radiasi padi lokal Aceh yang diuji mampu bertahan dari serangan penyakit HDB.

\section{DAFTAR PUSTAKA}

Abadi, L.A. 2003. Ilmu Penyakit Tumbuhan 2. Fakultas Pertanian Universitas Brawijaya. Bayumedia Publishing. Malang

Advertorial, BATAN. 2013. Mira-1, Varietas Unggul Hasil Riset Nuklir. Diakses pada tanggal 25 juli 2017. https://www.liputan6.com/news/read/762855/mira-1-varietas-unggul-hasil-riset-nuklir

Anggraini, F., A. Suryanto, dan N. Aini. 2013. Sistem tanam dan umur bibit pada tanaman padi sawah (Oryza sativa L.) varietas Inpari 13. Jurnal Produksi Tanaman 1 : 2. http://protan.studentjournal.ub.ac.id/index.php/protan/article/view/19

Agrios, G. N. 2005. Plant Pathology 5th edition. Elsevier Academic Press-London, UK.

Balai Besar Penelitian Tanaman Padi (BBPTP). 2009. Deskripsi Tanaman Padi. Sukamandi

CABI. 2008. Xanthomonas oryzae. Bulletin CABI and EPPO for the EU. Pp. 8.

Chen S, Xu CG, Lin XH and Zhang Q (2003) Improving bacterial blight resistance of 6078, an elite restorer line of hybrid by molecular marker assisted selection. Plant Breed.120: 133-137.

Herlina, L. dan T.S.,Silitonga. 2011. Seleksi lapang ketahanan beberapa varietas padi terhadap infeksi hawar dan bakteri strain IV dan VII. Buletin Plasma Nutfah. 17(2).

International Rice Research Institute (IRRI). 2014. Standart Evaluation System for Rice. $\quad$ 5th ed.IRRI. Los Banos. Philippines.

Liu, D.N., Ronald P.C. dan Boddanova, A.J. 2006. Xanthomonas oryzae pathovars: model pathogens of a model crop. Mol Plant Pathol. 7:57-59.

Ogawa, T. 1993. Methods and strategy for monitoring race distributions and identifications of resistance genes to bacterial leaf blight (Xanthomonas campestris pv. oryzae) in rice. JAEQ 27:71-81.

Lalitha, M.S., G. Lalitha Dewi, G. Naveen Kumar, and H.E. Shashidhar. 2010. Molecular marker-assisted selection: A tool for insulating line of hibryd rice against bacterial leaf blight. Int. Jour. Of Plant Pathology 1: 114-123.

Norsalis, E., 2011. Padi Gogo dan Padi Sawah. USU. Diakses dari http://repository.USU.ac.id/bitstream/123456789/17659/4/Chapter\%20II.pdf, pada 16 Januari 2020.

Suparyono. Sudir dan Suprihanto. 2004. Komposisi patotipe patogen hawar daun bakteri pada tanaman padi stadium tumbuh berbeda. Jurnal Penelitian Tanaman Pangan. 22(1) : 45-50. Jakarta.

Suryadi, Y. dan T.S., Kadir,. 2008. Kajian infeksi Xanthomonas oryzae pv. oryzae terhadap beberapa genotipe padi : hubungan kandungan hara dengan intensitas penyakit. Ilmu Pertanian. 15(1) : $26-36$.

Song J.Y., D.S Kim, M.C. Lee, K.J. Lee, J.-B.Kim, S.H, B.-K.Ha, S.J. Yun, and S,Y. Kang. 2012. Physidogical characterization of gamma-ray induced salt tolerant rice mutant. Australian Journal of plant Science, 6(3) : 421-429. 
Marlina, Lukman Hakim, dan Efendi. Uji Ketahanan Beberapa Galur Padi Smart Hasil Mutasi Radiasi Padi Lokal Aceh Dengan Teknologi Sinar Gamma Terhadap Penyakit Hawar Daun Bakteri (Xanthomonas oryzae pv. oryzae)

Wening, R.H., U. Susanto dan Sasoto. 2016. Varietas Unggul Padi Tahan Hawar Daun Bakteri: Perakitan dan Penyebaran di Sentra Produksi. Iptek Tanaman Pangan. Sukamandi. 11(2). 